\title{
Failure to Launch: The Unfulfilled Promise of Eportfolios in Irish higher education: An Opinion Piece
}

\author{
Dr. Orna Farrell \\ Programme Chair- BA Humanities, BA English \& History, BA Single Module \\ DCU Connected, National Institute for Digital Learning, Dublin City University \\ Dublin, Ireland \\ (C) Orna Farrell. This work is licensed under the Creative Commons Attribution- \\ NonCommercial-ShareAlike 4.0 International License. To view a copy of this license, visit \\ https://creativecommons.org/licenses/by-nc-sa/4.0/ .
}

\begin{abstract}
In this article, the unfulfilled promise of eportfolio in Irish higher education is critiqued. The article analyses the factors that have led to the slow pace of eportfolio adoption in Ireland, in contrast to the ubiquitous nature of eportfolio practice in higher education worldwide. The emergence of an Irish eportfolio community indicates that eportfolio are gaining traction in Irish higher education but to fulfil their promise academics need to be supported in their professional development, funding is required for empirical research and a greater understanding of eportfolio purposes and pedagogy should be developed in the Irish academic community.
\end{abstract}

\section{Introduction}

This article considers why eportfolio practice has not emerged at scale in Irish higher education, this trend is out of alignment with the ubiquitous nature of eportfolio practice in higher education worldwide (Harding, 2018). In the context of Irish higher education, the unfilled promise refers to the absence of campus wide, institutional and sectoral approaches to eportfolio. The slow pace of adoption of eportfolios in Ireland is due to three factors: a lack of government policy drivers; no distinct Irish eportfolio community; and a scarcity of funding.

An eportfolio can be defined in many ways as it can fulfil many functions, it can be a tool or technology, a practice, a pedagogical model, an assessment method and a framework for learning (Chen and Black, 2010). A learning-oriented eportfolio definition by Corley and Zubizarretta (2012, p.65) conceptualises it as "a vehicle for bringing together judiciously selected samples of students' work and achievements inside and outside the classroom for authentic assessment over time... it becomes more than a product, a simple repository of artefacts; it becomes a process".

Originating from eighteenth-century Italy, portfolios were used by artists, musicians, writers, and architects to carry, protect and show their work (Bryant and Chittum, 2013). Portfolio assessment began in the 1980's in America. Emerging from the 
disciplines of Teacher Education, Art and English and used by students to collect their work and reflect on what they had learned (Lorenzo and Ittelson, 2005). In the early 1990's, electronic portfolios emerged, harnessing the technologies of the digital revolution, in conjunction with the growth of learner centred and constructivist learning theories. The new forms of learning enabled by Web 2.0 technologies combined with a growing attention in higher education quality and the measurement of learning through outcomes-based assessment further increased eportfolio practice in higher education around the world (Eynon and Gambino, 2017).

There is growing evidence of the impact of eportfolio practice on student learning, research suggests that eportfolio based assessment enables students to integrate their learning and make connections between modules in an authentic and meaningful way (Buente et al., 2015; Eynon and Gambino, 2017; Morreale et al., 2017). Further, the literature indicates that learning with an eportfolio can foster a sense of belonging to a community and collaboration with peers (Barbera, 2009; Bolliger and Shepherd, 2010). In addition, research indicates that eportfolios can enable students to learn in a self-regulated way (Alexiou and Paraskeva, 2010; Jenson, 2011; Nguyen and Ikeda, 2015).

\section{Eportfolios around the world}

Eportfolios are increasingly common in higher education around the world. In America, $57 \%$ of colleges are using eportfolios (Eynon and Gambino, 2017). Similarly, in the UK, $78 \%$ of universities have an institutional eportfolio platform (UCISA, 2014). The scale of eportfolio adoption in New Zealand is truly widespread, where every educational institution has access to a government supported and developed eportfolio called MyPortfolio based on the Mahara platform (Maher and Gerbic, 2009). In order to facilitate the transparent recognition of skills and qualifications in Europe, the Europass eportfolio was created in 2000 by the European Union. The Europass makes the users' skills and qualifications clearly and easily understood in Europe (Europass, 2018).

\section{Drivers for adoption}

Based on a critical analysis of the eportfolio literature, Farrell (2018) identifies three drivers of eportfolio adoption in higher education: government policy; eportfolio communities; and funding for eportfolio practice and research. These drivers are present in all of the countries, such as America, UK, and New Zealand, where eportfolio has been adopted successfully at scale in higher education.

Government policy can impact eportfolio adoption; for example, in the UK, one of the major drivers of eportfolio adoption was the government policy on Personal Development Planning (PDP) which was first featured in the Dearing Report (Dearing, 1997) which recommended the introduction of student progress files "a means by which students can monitor, build and reflect upon their personal development". In 2001, the Higher Education Quality Assurance Agency (QAA) built on this 
recommendation and published guidelines that included a minimum level of institutional engagement with PDP. In response to the QAA policy on PDP, many UK Universities began using eportfolio tools to support PDP. This was a key driver for institutional eportfolio initiatives (Joyes, Gray, and Hartnell-Young 2010; Strivens and Ward, 2010).

Communities of practice are of central importance to successful eportfolio implementation and adoption. In countries where strong vibrant communities developed, there is a clear link to widespread eportfolio practice. One of the most effective ways of fostering scholarship and research in higher education is to form a community. This concept is based on Wenger's theory of community of practice (1998, p.6) which is defined as "a group of people who share a concern or a passion for something they do, and learn how to do it better as they interact regularly."

An example of a thriving eportfolio community based in the USA and Canada is the Association for Authentic Experiential and Evidence Based Learning (AAEEBL) founded in 2009 which has hundreds of members based in higher education. AAEEBL holds several annual conferences and publishes a journal The International Journal of Eportfolio (AAEEBL, 2018). The AAEEBL community is very active and promotes evidence-based approaches to eportfolio practice which focus on pedagogy.

Government funding for eportfolio practice and research is fundamental to widespread eportfolio adoption at higher education level. This is evident in Australia where the Australian Eportfolio Project (AeP) 2007-2010 was funded by the government through the Carrick Institute for Learning and Teaching in Higher Education. This research study investigated approaches of eportfolio use by students in Australian universities in relation to the scope, penetration, reasons for use and implementation of eportfolio (Hallam and Creagh, 2010). The project provided a snapshot of eportfolio use in Australia at the time and identified policies and standards to foster eportfolio use in higher education (Hallam and Creagh, 2010). As part of the project, an eportfolio community was founded and annual conference was established, both of which have been critical to the fostering of a vibrant eportfolio community in Australia.

\section{What about Ireland?}

In Ireland there is an absence of explicit government policy specifically in relation to the adoption of eportfolio in higher education, compared to the government policy drivers in the UK, U.S., Australia and New Zealand. In Ireland, the current mission of higher education, as stated in the National Strategy for Higher Education to 2030 (The Hunt Report) is to widen participation, increase student numbers, improve retention and become much more flexible (DES, 2011). In response to this strategy, the National Forum for the Enhancement of Teaching and Learning was created in 2012. One of its objectives is to build the digital capacity of Irish higher education. The National Forum's report (2014, p. ix) A Road Map For Enhancement in a Digital World 20152017 recommends that Ireland "develop a consistent, seamless and coherent digital 
experience for students in Irish higher education and actively engage with students and teachers to develop their digital skills and knowledge".

The increased focus on key skills in Ireland is due to the introduction of the National Framework for Qualifications (NFQ) in 2003, which reframed learning achievements and award classifications and levels. Standards for learning achievement levels were framed in the context of a person's knowledge, skill, and competence (QQI, 2015). There is growing evidence that eportfolio based learning has the potential to support many of these higher education objectives. However, to date there has been minimal engagement by Irish higher education institutions (Baird, Gamble and Sidebotham, 2016; Eynon and Gambino, 2017; Lambe, McNair, and Smith, 2013; Morreale et al., 2017).

The NMC Horizon Report, Higher Education in Ireland, from 2015 offers an explanation for the slow pace of eportfolio adoption in Irish higher education: a lack of sufficient institutional resources and infrastructure to effectively adopt and integrate new technologies, outdated infrastructure, inadequately resourced virtual learning environments and lack of investment in new and emerging media (Johnson et al., 2015).

There is a small body of empirical research on eportfolio practice in Ireland. A recent search of the ERIC database found only four peer-reviewed journal articles about eportfolios in Ireland (Donaldson et al., 2018). Two recent studies of Irish academics found that $31 \%$ were beginning to use eportfolios and $69 \%$ stated they were not using eportfolios in their practice (Eportfoliohub, 2016; Harding, 2018). Eportfolio Hub was a national project funded by the National Forum for the Enhancement of Teaching and Learning which culminated in a dissemination event comprising presentations from higher education institutions around Ireland. (Eportfoliohub, 2016). It is clear that traditional forms of assessment still dominate in Irish higher education; however, there are indications that pockets of Irish higher education institutions are beginning to engage with eportfolio. Dublin City University has recently introduced a campus wide learning portfolio called Loop Reflect for 16,000 students in May 2017 (O’Brien, 2017).

\section{An emerging Irish eportfolio community}

Since 2017, an Irish eportfolio community of practice has been emerging. Initially called Maharalrl, then rebranded Eportfolio Ireland in 2018. Eportfolio Ireland has a growing membership of practitioners from higher and further education (Donaldson et al., 2018). Eportfolio Ireland is a practitioner led organisation which holds online and face to face professional development events and has recently produced a co-created open access online book called Eportfolio based assessment: Inspiring exploration \& supporting evaluation for practitioners.

\section{A typology of eportfolio purposes}

As a digital tool, it seems from the evidence that an eportfolio has many affordances and can be used flexibly for a variety of purposes in higher education. While the 
flexibility of the eportfolio may be viewed as a benefit; however, in practice, this can be a source of confusion and a barrier to successful introduction of eportfolio practice at an institutional level, as the clear purpose of eportfolio practice must be clear and explicit to students and academic staff (An and Wilder, 2010; Gaitan, 2012; Scholz, Tse and Lithgow, 2017; Wuetherick and Dickinson, 2015).

There are four uses and purposes for eportfolio practice in higher education (Farrell, 2018):
1. Assessment
2. Developmental
3 Placement
4. Careers

\section{Assessment}

Eportfolios can take many forms, depending on the purpose, the programme, the disciplinary context, and the desired learning outcomes (Farrell, 2018). Portfolios have become a common form of summative assessment across all disciplines in higher education (Lowenthal, White and Cooley, 2011). The rationale for adopting eportfolios for assessment is twofold: firstly, eportfolios can be an authentic, meaningful and student-centred form of assessment because it captures evidence of student learning in context and over time (Buyarski and Landis, 2014; Chen and Penny Light, 2010; Eynon and Gambino, 2017). Secondly, eportfolio assessment is a valid and reliable method of assessment of students' demonstration of learning outcomes (Buyarski and Landis 2014; Eynon and Gambino, 2017).

Best practice for summative assessment using eportfolio according to the literature is that eportfolio should be programme-focused and form a core of a programme's assessment design rather than bolted on. It should be thoughtfully woven throughout the curriculum, capturing the student learning experience over the duration of the degree (Clarke and Boud, 2018; Housego and Parker, 2009; Klenowski, Askew and Carnell, 2006; Shepherd and Bolliger, 2014; Simatele, 2015).

\section{Developmental}

There is a developmental aspect to all portfolio-based learning, in fact, it is a fundamental principle that evidence, reflections, and artefacts are compiled incrementally over time.

However, only two types of eportfolio specifically have development as their purpose: process portfolio and a personal development portfolio (PDP). Although they share the common purpose of development, they have different aims. The process portfolio focuses on learning and the documenting of the process of learning, while a personal development portfolio focuses on planning and goal setting. One of the key differences between process portfolios and other portfolios such as assessment or career portfolios, is that process portfolios are focussed on the process of learning, rather 
than final polished product or showcase eportfolio. Klenowski, Askew and Carnell (2006) argue that there has been a shift from the traditional view of portfolio as a collection of work to a learning portfolio which focuses on learning.

\section{Placement}

Using an eportfolio to document student experience while on a placement, practice, or practicum is one of the most common purposes of eportfolio in a higher education context. Disciplines where placement are central to student learning such as teacher education and health and medical sciences have been early adopters of eportfolio (Parker, Ndoye and Ritzhaupt, 2012).

\section{Careers}

The main purposes of career eportfolio are to support students' transitioning from higher education to the workplace and to develop students' employability skills (Simatele, 2015; Von Kronsky and Oliver, 2012). In fact, Taylor and Rowley (2017) argue that graduates applying for jobs with an eportfolio have a significant advantage over those applying with a traditional CV. Employers appear to becoming more comfortable with reviewing eportfolio as part of their recruitment processes, the Association of American Colleges and Universities carried out a survey of 318 employers in 2013 in which $80 \%$ said they found eportfolio useful when reviewing applicants (Ring, Waugaman and Brackett, 2017). Further, students are beginning to value an eportfolio as a means of enhancing their employability post-graduation. In an Australian study carried out by Von Kronsky and Oliver (2012) which examined how students were using their eportfolio in an Australian university, 52\% of students reported that one of the key reasons for them to use the eportfolio was that they thought it would help with their employability.

\section{Concluding Thoughts}

Eportfolio based learning can be a powerful medium for enabling meaningful and authentic learning for students. As eportfolios become more prevalent in Ireland, higher education institutions must focus on the pedagogy and the learning opportunities that a well-designed eportfolio can enable. Institutional initiatives should be underpinned by explicit and robust government policy. Academic staff must be supported in their professional development in relation to eportfolio use. Finally, funding for empirical research on eportfolio has to be provided along with the need to develop and facilitate greater understanding of eportfolio purposes and pedagogy sector wide.

\section{References}

Alexiou, A. and Paraskeva, F. (2010) 'Enhancing self-regulated learning skills through the implementation of an e-portfolio tool', Procedia Social and Behavioral Sciences, 2(2), pp. 3048-3054. 
An, H. and Wilder, H. (2010) 'A bottom-up approach for implementing electronic portfolios in a teacher education program'. Journal of Computing in Teacher Education, 26(3), pp. 84-91.

Association for Authentic, Experiential, and Evidence-Based Learning (2018) About. Available at: https://aaeebl.org/about/ (Accessed: 24 February, 2018).

Baird, K., Gamble, J. and Sidebotham, M. (2016) 'Assessment of the quality and applicability of an e-portfolio capstone assessment item with a bachelor of midwifery program', Nurse Education in Practice, 20, pp. 11-16.

Barbera, E. (2009) 'Mutual feedback in e-portfolio assessment: an approach to the netfolio system', British Journal of Educational Technology, 40(2), pp. 342-357.

Bolliger, D.U. and Shepherd, C.E. (2010) 'Student perceptions of eportfolio integration in online courses', Distance Education, 31(3), pp.295-314.

Bryant, L. and Chittum, J. (2013) 'ePortfolio effectiveness: a(n ill-fated) search for empirical support', International Journal of ePortfolio, 3(2), pp. 189-198. Available at: https://eric.ed.gov/?id=EJ1107810 (Accessed: 6 November 2018).

Buente, W., Winter, J.S., Kramer, H., Dalisay, F., Hill, Y.Z. and Buskirk, P.A. (2015) 'Programbased assessment of capstone eportfolios for a communication BA curriculum', International Journal of ePortfolio, 5(2), pp.169-179. Available at: https://eric.ed.gov/?id=EJ1107863 (Accessed: 6 November 2018).

Buyarski, C.A. and Landis, C.M. (2014) 'Using an eportfolio to assess the outcomes of a firstyear seminar: student narrative and authentic assessment', International Journal of ePortfolio, 4(1), pp. 49-60. Available at: https://eric.ed.gov/?id=EJ1107859 (Accessed: 6 November 2018).

Chen, H.L. and Black, T. (2010) 'Using eportfolio to support an undergraduate learning career: an experiment with academic advising', Educause Review. Available at: https://er.educause.edu/articles/2010/12/using-eportfolios-to-support-an-undergraduatelearning-career-an-experiment-with-academic-advising (Accessed: 6 November 2018).

Chen, H.L. and Penny Light, T. (2010) Electronic portfolios and student success: Effectiveness, efficiency, and learning. Washington: Association of American Colleges and Universities.

Clarke, J. L. and Boud, D. (2018) 'Refocusing portfolio assessment: Curating for feedback and portrayal', Innovations in Education and Teaching International, 55(4), pp. 479-486.

Corley, C.R. and Zubizarreta, J. (2012) 'The power and utility of reflective learning portfolios in honours', Journal of the National Collegiate Honors Council, 13(1), pp. 63-76 Spr-Sum. Available at: https://eric.ed.gov/?id=EJ1082249 (Accessed: 3 September 2017).

Dearing, R. (1997) Higher education in the learning society, Report of the National Committee of Enquiry into Higher Education. London: HMSO.

Department of Education and Skills (2011) National Strategy for Higher Education to 2030 Report of the Strategy Group. Dublin: Department of Education and Skills. Available at: 
http://hea.ie/assets/uploads/2017/06/National-Strategy-for-Higher-Education-2030.pdf (Accessed: 3 July 2017).

Donaldson, L., Buckley, K., Farrell, O. and Ui Choisdealbha, J. (2018) 'Reflections on eportfolio professional learning: harnessing an unconference approach', $A A E E B L$ Eportfolio Review [preprint], 3(1).

Eportfoliohub (2016) Project resources. Available at https://eportfoliohub.wordpress.com/ (Accessed: 9 November 2018) (Accessed: 3 September 2017). [couldn't find this webpage possibly moved]

Europass (2018) About Europass. Available at: http://europass.cedefop.europa.eu/ (Accessed: 6 July 2018).

Eynon, B. and Gambino, L. (2017) High impact eportfolio practice. Sterling: Stylus.

Farrell, O. (2018) Developing critical thinking through eportfolio based learning: an exploration of the experiences of non-traditional online distance learners. Unpublished PhD Thesis. Trinity College Dublin.

Gaitan, A. (2012) 'Understanding students' experiences of e-PDP and the factors that shape their attitudes', International Journal of ePortfolio, 2(1), pp.29-38. Available at: https://eric.ed.gov/?id=EJ1107616 (Accessed: 6 July 2018).

Harding, N. (2018) 'The digital turn: staff perceptions of the virtual learning environment and the implications for educational developers', The Irish Journal of Technology Enhanced Learning, 3(2).

Hallam, G. and Creagh, T. (2010) 'ePortfolio use by university students in Australia: a review of the Australian eportfolio project', Higher Education Research and Development, 29(2), pp. 179-194.

Housego, S. and Parker, N. (2009) 'Positioning eportfolios in an integrated curriculum', Education + Training, 51(5/6), pp. 408-421.

Jenson, J. (2011) 'Promoting self-regulation and critical reflection through writing students' use of electronic portfolio', International Journal of ePortfolio, 1(1), pp. 49-60. Available at: https://eric.ed.gov/?id=EJ1107586 (Accessed: 6 November 2018).

Johnson, L., Adams Becker, S., Cummins, M., Estrada, V. and Freeman, A. (2015) 2015 NMC Technology Outlook for Higher Education in Ireland: A Horizon Project Regional Report. Austin: The New Media Consortium. Available at: https://www.learntechlib.org/p/182055 (Accessed: 6 July 2018).

Joyes, G., Gray, L., and Hartnell-Young, E. (2010). Effective practice with e-portfolios: How can the UK experience inform implementation? Australasian Journal of Educational Technology, 26(1), 15-27. https://doi.org/10.14742/ajet.1099 (Accessed: 6 November 2018).

Klenowski, V., Askew, S. and Carnell, E. (2006) 'Portfolios for learning, assessment and professional development in higher education', Assessment and Evaluation in Higher Education, 31(3), pp. 267-286. 
Lorenzo, G. and Ittelson, J. (2005) 'An overview of e-portfolios', Educause Review. Available at: https://library.educause.edu/resources/2005/1/an-overview-of-eportfolios (Accessed: 6 July 2018).

Lambe, J., McNair, V. and Smith, R. (2013) 'Special educational needs, e-learning and the reflective e-portfolio: implications for developing and assessing competence in pre-service education', Journal of Education for Teaching, 39(2), pp. 181-196.

Lowenthal, P., White, J.W. and Cooley, K. (2011) 'Remake/remodel: using eportfolio and a system of gates to improve student assessment and program evaluation', International Journal of ePortfolio, 1(1), pp. 61-70. Available at: https:/leric.ed.gov/?id=EJ1107589 (Accessed: 1 February 2018).

Maher, M. and Gerbic, P. (2009) 'E-portfolios as a pedagogical device in primary teacher education: the AUT University experience', Australian Journal of Teacher Education, 34(5), pp. 43-53.

Morreale, C., Van Zile-Tamsen, C., Emerson, C.A. and Herzog, M. (2017) 'Thinking skills by design: a capstone eportfolio to promote reflection, critical thinking and curriculum integration', International Journal of Eportfolio, 7(1), pp. 13-28. Available at: https://eric.ed.gov/?id=EJ1142743 (Accessed: 5 May 2018)

National Forum for the Enhancement of Teaching and Learning in Higher Education (2014) A road map for enhancement in a digital world 2015-2017. Available at: https://www.teachingandlearning.ie/wp-content/uploads/2014/05/Digital-RoadmapPHASE1MAY282014.pdf (Accessed: 1 February 2018).

Nguyen, L.T. and Ikeda, M. (2015) 'The effects of eportfolio-based learning model on student self-regulated learning', Active Learning in Higher Education, 16(3), pp. 197-209.

O'Brien, C. (2017) 'Students to get 'living portfolios' aimed at boosting job prospects', The Irish Times, 24 May. Available at: https://www.irishtimes.com/news/education/students-to-getliving-portfolios-aimed-at-boosting-job-prospects-1.3094553 (Accessed: 1 November 2018).

Parker, M., Ndoye, A. and Ritzhaupt, A.D. (2012) 'Qualitative analysis of student perceptions of e-portfolio in a teacher education program', Journal of Digital Learning in Teacher Education, 28(3), pp. 99-107.

QQI (2015) National Framework of Qualifications. Available at: https://www.qqi.ie/Articles/Pages/National-Framework-of-Qualifications-(NFQ).aspx (Accessed: 5 May 2018).

Ring, G.L., Waugaman, C. and Brackett, B. (2017) 'The value of career eportfolios on job applicant performance: using data to determine effectiveness', International Journal of ePortfolio, 7(2), pp. 225-236. Available at: http://theijep.com/pdf/IJEP259.pdf (Accessed: 5 May 2018).

Scholz, K., Tse, C. and Lithgow, K. (2017) 'Unifying experiences: learner and instructor approaches and reactions to eportfolio usage in higher education', International Journal of ePortfolio, 7(2), pp. 139-150. Available at: https://eric.ed.gov/?id=EJ1159901 (Accessed: 6 July 2018). 
Shepherd, C.E. and Bolliger, D.U. (2014) 'Managing communication and professional development in online graduate programs with electronic portfolios', Online Journal of Distance Learning Administration, 17(2).

Simatele, M. (2015) 'Enhancing the portability of employability skills using e-portfolios', Journal of Further and Higher Education, 39(6), pp. 862-874.

Strivens, J. and Ward, R. (2010) 'An overview of the development of Personal Development Planning (PDP) and e-Portfolio practice in UK higher education', Journal of Learning Development in Higher Education.

Taylor J. and Rowley J. (2017) 'Building professional capabilities: eportfolio as developmental ecosystems', in: Rowley J. (ed.) Eportfolio in Australian Universities. Singapore: Springer, pp. 191-203.

UCISA: Universities and Colleges Information Systems Association. (2014). 2014 Survey of technology enhanced learning for higher education in the UK [online]. Available at: http://www.ucisa.ac.uk/ /media/groups/dsdg/Tel 2014 Final 18 August.ashx (Accessed: 9 June 2018).

Von Kronsky, B.R and Oliver, B. (2012) 'The iportfolio: measuring uptake and effective use of an institutional electronic portfolio in higher education', Australasian Journal of Educational Technology, 28(1), pp. 67-90. Available at: https://ajet.org.au/index.php/AJET/article/view/884 (Accessed: 9 June 2018).

Wenger, E. (1998) Communities of practice: learning, meaning and identity. London: Cambridge.

Wuetherick, B. and Dickinson, J. (2015) 'Why eportfolio? student perceptions of eportfolio use in continuing education learning environments', International Journal of ePortfolio, 5(1), pp. 39-53. Available at https://eric.ed.gov/?id=EJ1107862 (Accessed: 12 February 2018). 